2020, Volume 14, International Conference Innovative Business Management \& Global Entrepreneurship (IBMAGE 2020), pages: 312-325 |

https://doi.org/10.18662/lumproc/ibmage2020/23

\section{Evolution of} consumption expenditures of population of the Republic of Moldova

\section{Mircea GUTIUM ${ }^{1}$}

${ }^{1}$ National Institute for Economic Research, Chisinau, Republic of Moldova, gutium.mircea@,rambler.ru
Abstract: Consumption expenditures is one of the key indicators that reflects the purchasing power of the population. Purchasing power in turn shows the level of social welfare. The population with a stable evolution of consumer spending is at least able to maintain its level of consumption with inflation. In addition, if consumer spending rises in proportion to the level of inflation, there is an increase in welfare and living standards. High level of consumption has positive influence on business. greater aggregate demand will generate more profits, boost company development, and foster job creation. In this study, the affirmation was verified that the consumer price index is one of the factors that influence the standard of living, but not primarily. The following scientific methods were used to approve or reject the statement: scientific abstraction, analysis and synthesis, graphical and tabular method, comparative analysis method, correlation and regression analysis. In this study there was made comparison of consumption evolution and its structure in the Republic of Moldova and in the European Union to identify the difference in welfare. The linear regression model between the consumer price index and growth rate of household expenditures was elaborated.

Keywords: Consumption expenditures, disposable income, consumer price index, well-being, living standards.

How to cite: Gutium, M. (2020). Evolution of consumption expenditures of population of the Republic of Moldova. In M. W. Staniewski, V. Vasile, \& A. Grigorescu (vol. ed.), Lumen Proceedings: Vol. 14. International Conference Innovative Business Management \& Global Entrepreneurship (IBMAGE 2020) (pp. 312-325). Iasi, Romania: LUMEN Publishing House. https://doi.org/10.18662/lumproc/ibmage2020/23 


\section{Introduction}

This article crystallizes the relationship between inflation and the level of consumer spending. Being the most relevant indicator of well-being consumer spending needs to be analysed from all points of view for a better understanding of the economic links with other phenomena, such as inflation.

\section{Problem Statement}

In the scientific literature there are papers that study effects of inflation on standard of living with Paired t-test for Pakistan [4] and Ethiopia [6], but there are not analogical studies for the Republic of Moldova. Another difference is the fact that not the Paired t-test method is used, but the correlation and regression analysis for elaboration the regression model.

\section{Research Questions/Aims of the research}

The object of research is living standards. The main purpose is to analyse the correlation between consumption expenditures and the consumer price index.

The following tasks have been set: analysis of the evolution of consumption expenditure of population of the Republic of Moldova and its structure; analysis of the disposable income of population of the Republic of Moldova; analysis of the consumption of population of the European Union and comparison with the consumption in Moldova; establishing the correlation between household expenditures and consumer price index in the Republic of Moldova.

\section{Research Methods}

In this research, the author relied on data from the National Bureau of Statistics and Eurostat data. In this study were used the method of correlation and regression analysis for prove or reject the assertion that the consumer price index has a significant impact on consumption. The data series for the elaboration of the regression model contain 14 observations. 


\section{Findings}

\subsection{Evolution of the living standard of population of the Republic of Moldova}

The level and structure of consumer spending is an eloquent way to identify the level of living standard of the population. In the scientific literature it could be found the statement that, if the growth of the consumption level is higher than the growth of the price index, the purchasing power of the population would be increasing. There are factors that directly affect the formation of the standard of living, and factors that have an indirect impact on it, that is, causing it.

The factors directly affecting the formation of the standard of living include: the level of income of the population; the volume and structure of consumption of material goods; housing provision; the level of health care development; the level of development of education; the level of cultural development; the level of social security; the amount of free time; rest conditions, etc.

The factors that determine the standard of living includes the degree of employment of the able-bodied population; working hours; labor intensity; the state of labor protection and safety at work [1].

The factors that shape the standard of living characterize the living conditions of people outside the sphere of material production. Factors that indirectly affect the standard of living of people, as well as working conditions, are factors that are formed in production and are determined by the level of its development.

The most significant factors that determine the dynamics of the standard of living of the population include the level of productive forces and relations of production in society, technological progress, the economic potential of society (its national wealth), methods of distribution of the social product, political and social factors [7].

All factors are closely interdependent and require their comprehensive consideration when solving the problem of raising the standard of living in the country.

Of course, countries with efficient economies and significant social wealth are able to provide their citizens with higher living standards and social guarantees than economically backward countries [5]. The same is true for countries with a predominantly able-bodied population and high employment rates.

The evolution of consumer spending of individuals in the Republic of Moldova has a positive trend over the past 5 years being 1052.8 lei more in 2019 compared to 2014 (Figure 1). The difference between consumer spending and 
average salary was 4447.2 lei in 2019; it is explained by the presence of family members who do not have a source of income [3].

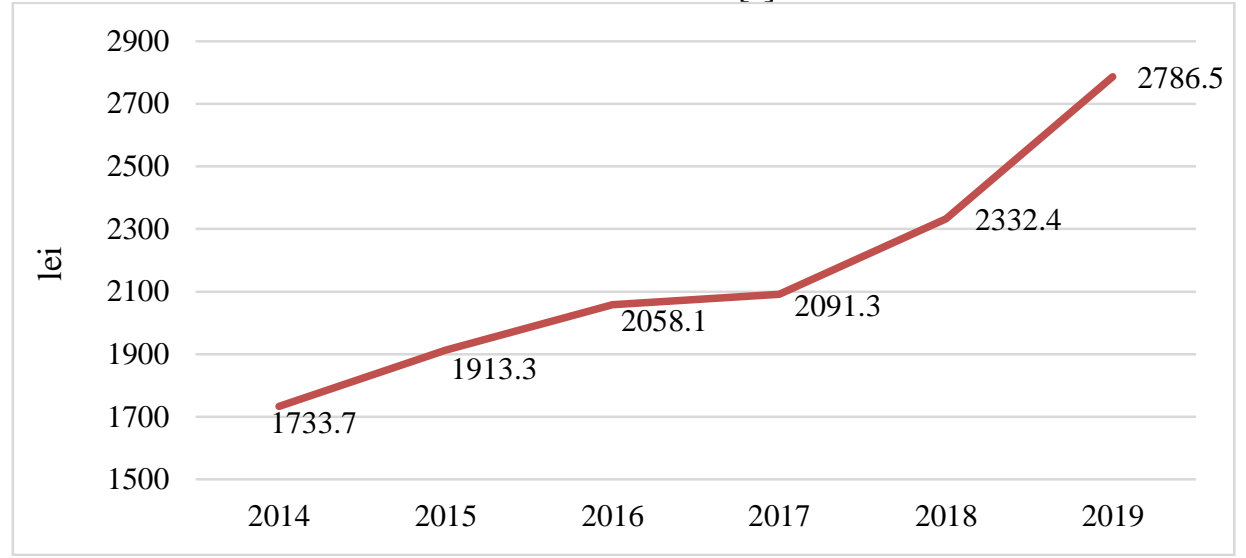

Figure 1. Evolution of consumption expenditure

(average monthly per capita, lei), Republic of Moldova, 2014-2019

Source: Author representation

Most of the consumption expenditures of the population of the Republic of Moldova, namely 1130.8 lei per month at the end of 2019 were oriented towards food procurement, which accentuates the low standard of living of the population of the Republic of Moldova. (Figure 2).

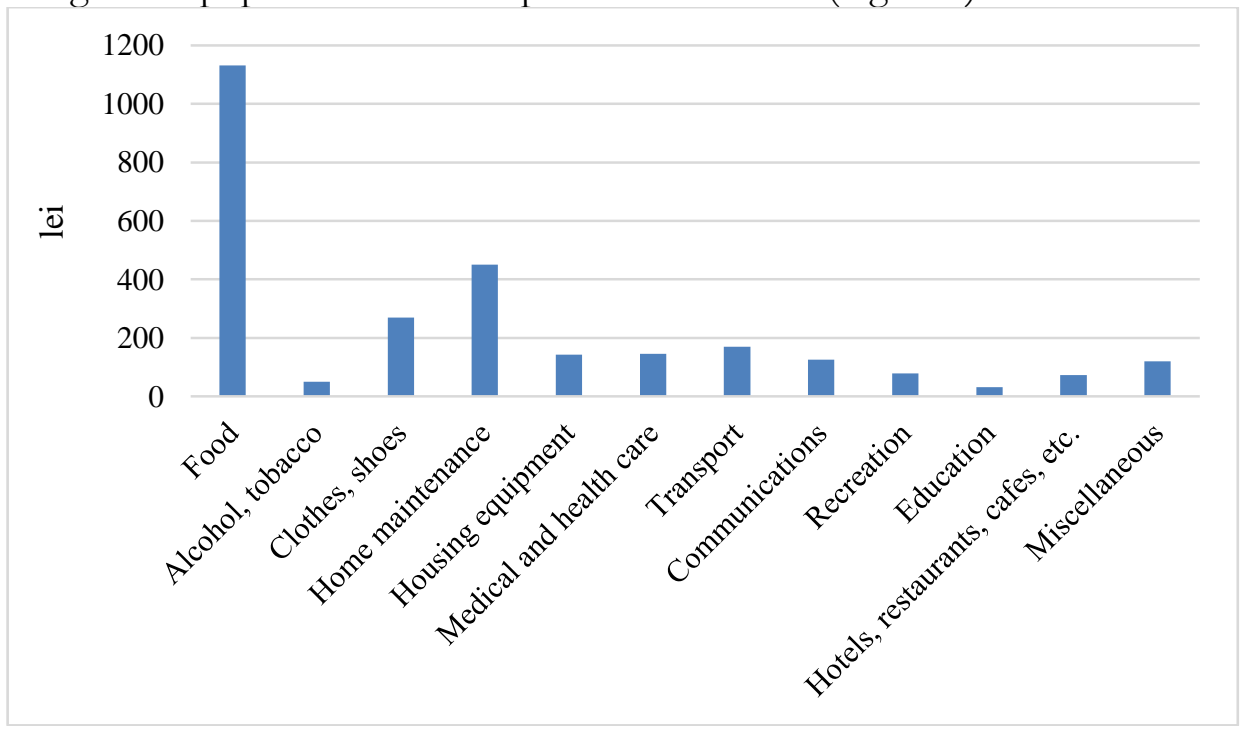

Figure 2. Consumption expenditure (average monthly per capita, lei),

Republic of Moldova, 2019

Source: Author representation 
In second place is the maintenance of the home, then spending on clothing and footwear, as a result for other expenses do not remain sufficient resources to meet them.

Opposite, in developed countries most of the consumption expenditures of the population were oriented on services or luxury consumption.

In Figure 3 illustrates the evolution of consumption expenditures in lei per capita in rural and urban areas. Traditionally, consumer spending in urban areas is higher than in rural areas due to higher incomes in urban areas. The process of urbanization and the extinction of villages is carried out in connection with the concentration of finance in large cities.

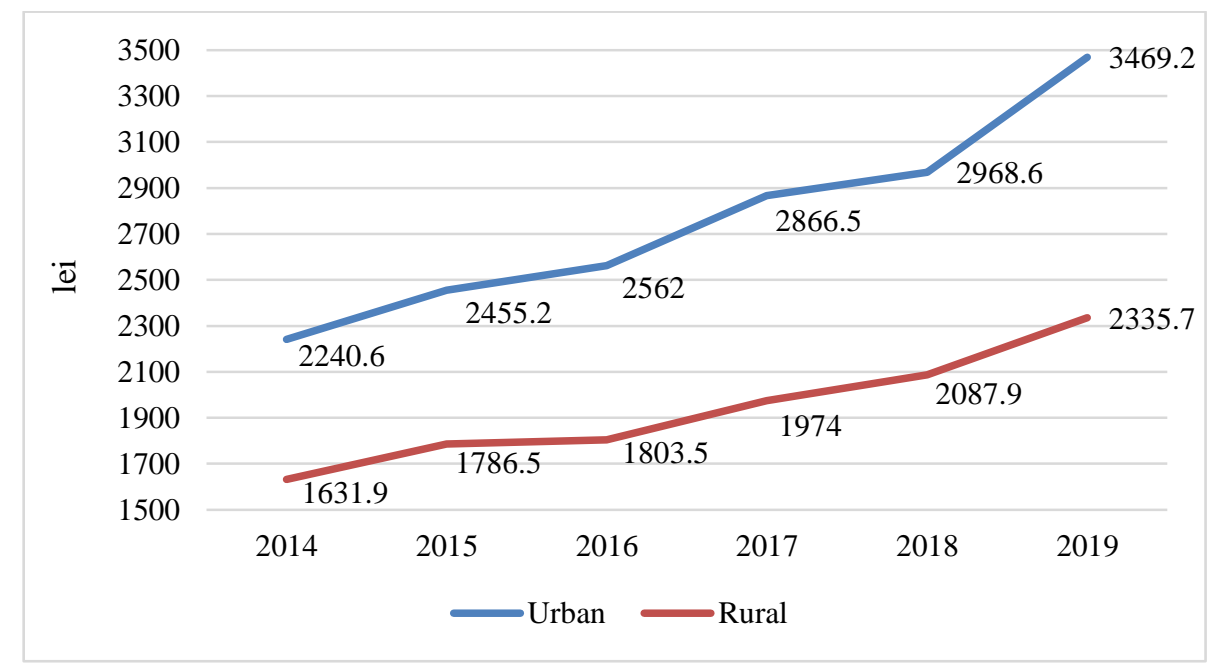

Figure 3. Evolution of consumption expenditure by area, Republic of Moldova, 2014-2019

Source: Author representation

According to Table 1 we can see the structure of consumer spending in the Republic of Moldova and its level by groups. Food for several years holds the leading position in the structure of expenditures of the population of the Republic of Moldova, which illustrates a low standard of living in this country.

Another significant item of expenditure was home maintenance, which amounted to 451.1 lei in 2019. But the share of these expenditures decreased and reached $16.19 \%$ in 2019, i.e. 2.55 percentage points less than in 2014 .

Some expense items have increased approximately 2 times or more: hotels, restaurants, cafes, etc. (2.7 times), recreation (2.5 times), education (2.2 times), transport (2.0 times). 
Table 1. Consumption expenditure by consumer spending group,

Republic of Moldova, lei

\begin{tabular}{|c|c|c|c|c|c|c|}
\hline $\begin{array}{l}\text { Consumer } \\
\text { spending group }\end{array}$ & 2014 & 2015 & 2016 & 2017 & 2018 & 2019 \\
\hline $\begin{array}{l}\text { Consumption } \\
\text { expenditure - } \\
\text { total }\end{array}$ & 1893.7 & 2072.9 & 2129.8 & 2359.5 & 2473.7 & 2786.5 \\
\hline \multicolumn{7}{|l|}{ of which: } \\
\hline Food & 812.9 & 897.0 & 934.4 & 1000.6 & 1070.2 & 1130.8 \\
\hline $\begin{array}{l}\text { Alcohol, } \\
\text { tobacco }\end{array}$ & 27.8 & 30.2 & 30.8 & 34.5 & 36.9 & 50.4 \\
\hline Clothes, shoes & 210.9 & 228.8 & 229.9 & 249.8 & 269.2 & 269.1 \\
\hline $\begin{array}{l}\text { Home } \\
\text { maintenance }\end{array}$ & 354.9 & 364.9 & 368.2 & 414.3 & 447.2 & 451.1 \\
\hline $\begin{array}{l}\text { Housing } \\
\text { equipment }\end{array}$ & 74.2 & 84.4 & 92.9 & 97.8 & 97.4 & 142.2 \\
\hline $\begin{array}{l}\text { Medical and } \\
\text { health care }\end{array}$ & 98.5 & 122.6 & 126.4 & 140.9 & 117.6 & 145.2 \\
\hline Transport & 83.9 & 94.8 & 70.0 & 92.1 & 115.6 & 170.0 \\
\hline Communication & 79.1 & 86.9 & 119.7 & 109.0 & 115.1 & 125.7 \\
\hline Recreation & 32.0 & 25.9 & 23.4 & 35.5 & 30.7 & 78.6 \\
\hline Education & 14.0 & 14.8 & 12.7 & 15.5 & 15.2 & 31.4 \\
\hline $\begin{array}{l}\text { Hotels, } \\
\text { restaurants, } \\
\text { cafes, etc. }\end{array}$ & 27.3 & 38.2 & 34.6 & 54.7 & 51.5 & 72.6 \\
\hline Miscellaneous & 78.2 & 84.4 & 86.8 & 114.8 & 107.1 & 119.4 \\
\hline
\end{tabular}

Source: Author representation

But the quotas of these items in expenditure structure are very small (Figure 4). The structure of household expenditure is largely allocated to basic necessities, such as food and household maintenance, and very little part is allocated to education, leisure and health. 


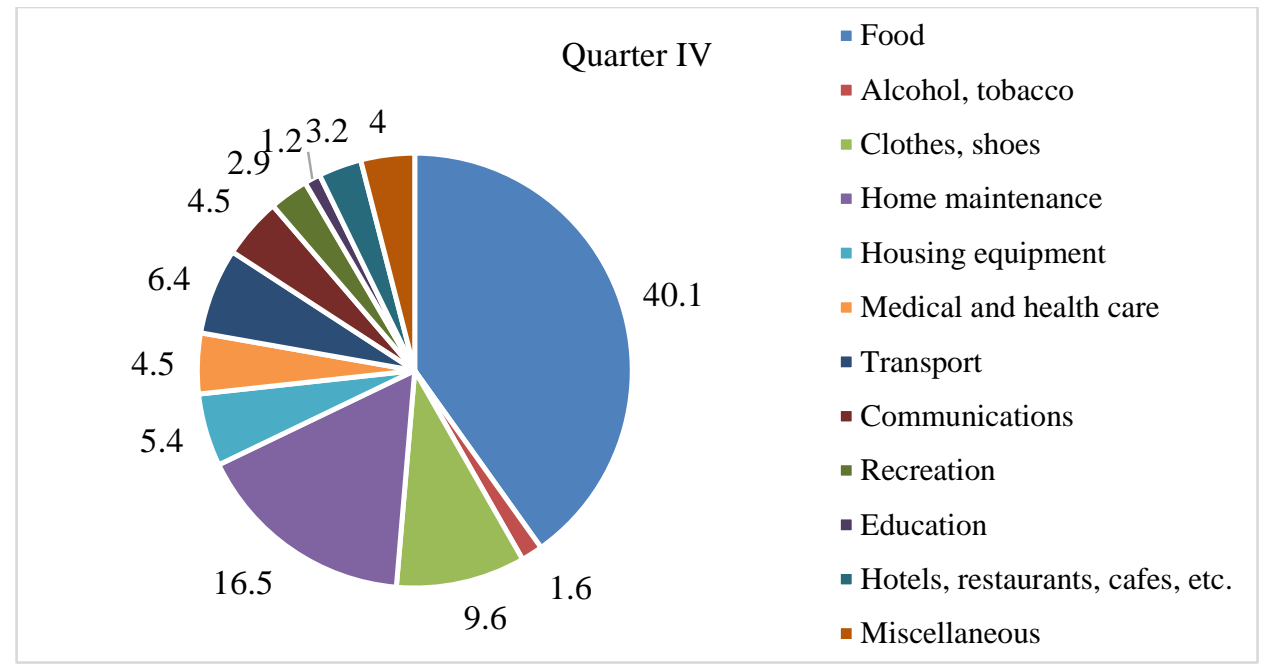

Figure 4. Structure of consumption expenditures, Republic of Moldova, 2019, \%

Source: Author representation

The quarterly evolution of consumption expenditures is determined by the evolution of the population's income. Thus, the least spent the population in the first quarter - 2660.1 lei, and the most in the second quarter - 2850.7 lei (Figure 5). The share of food expenditures showed fluctuating trends during the year, the lowest being recorded in the fourth quarter (40.1\%), and the highest in the second quarter $(41.1 \%)$.

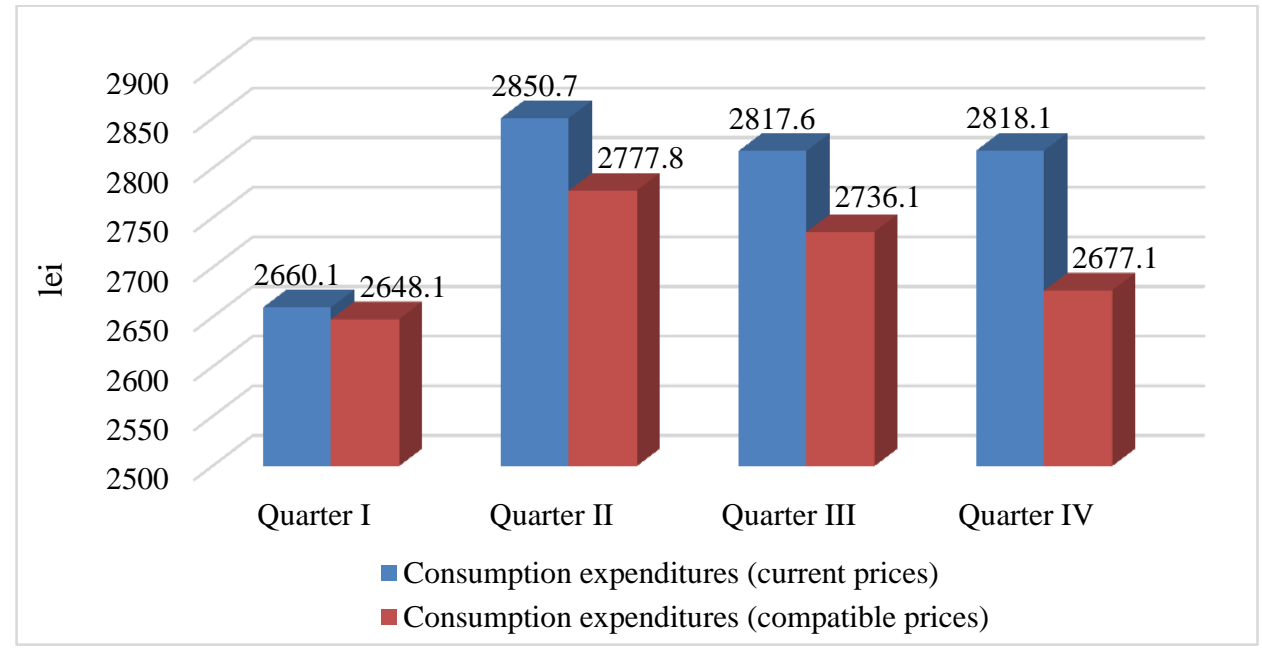

Figure 5. Quarterly evolution of consumption expenditures, Republic of Moldova, 2019

Source: Author representation 
So, the living standard of the population of the Republic of Moldova has increased insignificantly in 2014-2019, but its level remains very low compared to the standard of living in the countries of the European Union.

\subsection{Evolution of the disposable income of population of the Republic of Moldova}

The quarterly evolution of the population's incomes registered the oscillating trend during 2019. Thus, the lowest disposable income was registered in the first quarter - 2722.5 lei, and the highest ones in the second quarter 2934.2 lei. If we would take in account the level of inflation during the year, we find that disposable income in the fourth quarter increased compared to the first quarter by $2.8 \%$. The contribution of salary increased during the year from $48.3 \%$, in the first quarter, to $51.9 \%$ - in the fourth quarter.

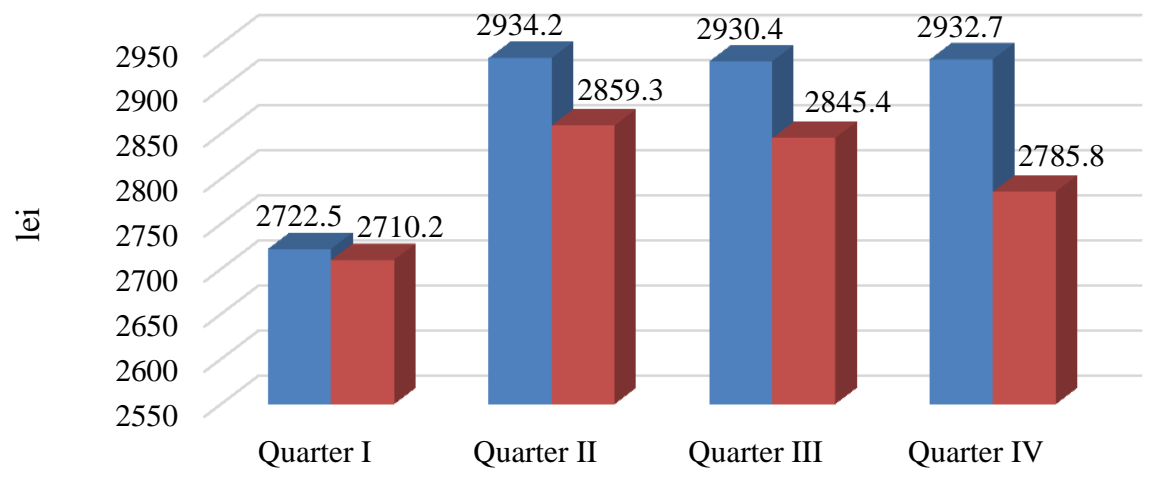

$\square$ Disposable income (current prices) $\quad$ Disposable income (compatible prices)

Figure 6. Quarterly evolution of disposable income, Republic of Moldova, 2019 Source: Author representation

Given that the urban population has higher incomes, respectively the consumption expenditures of this category of population are 1133.5 lei or 1.4 times higher than the expenditures of the rural population (Figure 7). In urban areas, $36.6 \%$ of monthly disposable income is allocated to providing food to the population, and in rural areas $-44.5 \%$ in 2019 . For the urban population, a higher share of expenditures was registered for: health services (5.6\% compared to $4.8 \%$ in rural areas), transport $(6.9 \%$ compared to $5.4 \%)$, leisure $(4.2 \%$ compared to $1.4 \%)$, education $(1.6 \%$ compared to $0.7 \%)$ and for hotels, restaurants and cafes $(4.4 \%$ compared to $0.8 \%)$. At the same time, for the rural population, a higher share in the structure occupies the expenditures for: clothing, footwear $(9.9 \%$ compared to $9.4 \%$ in urban areas), housing 
maintenance $(16.6 \%$ compared to $15.8 \%)$ and housing endowment (5.5\% compared to $4.7 \%)$.

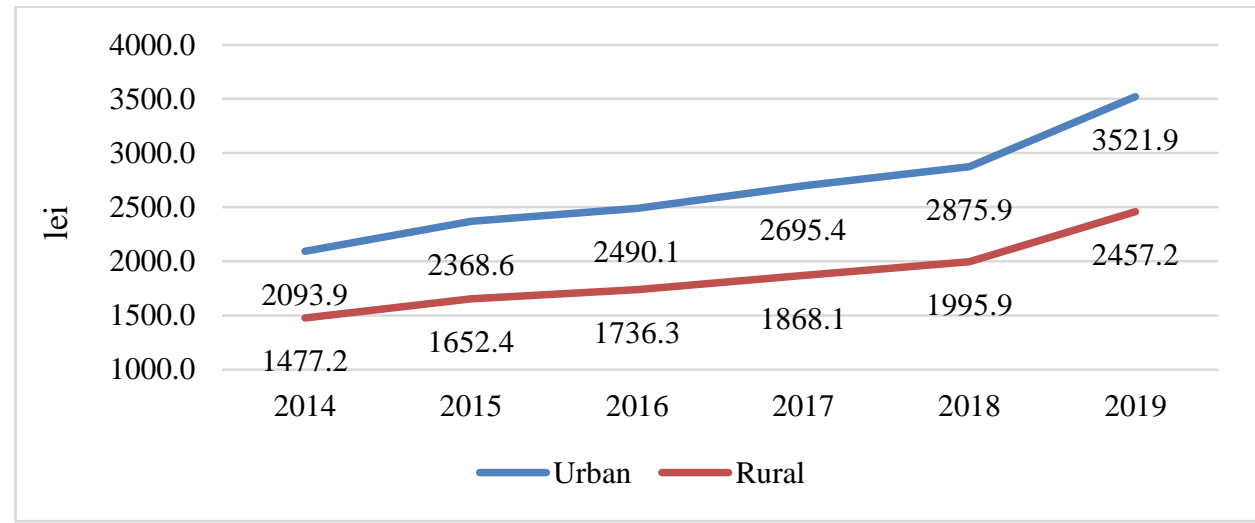

Figure 7. Evolution of disposable income by area,

Republic of Moldova, 2014-2019

Source: Author representation

According to Figure 8, household disposable income is also strongly influenced by its size, especially in the case of large households. If in singleperson households the average monthly disposable income per person is 3664.3 lei, then, for those that have 5 or more people, the income are 2 times lower (1859 lei).

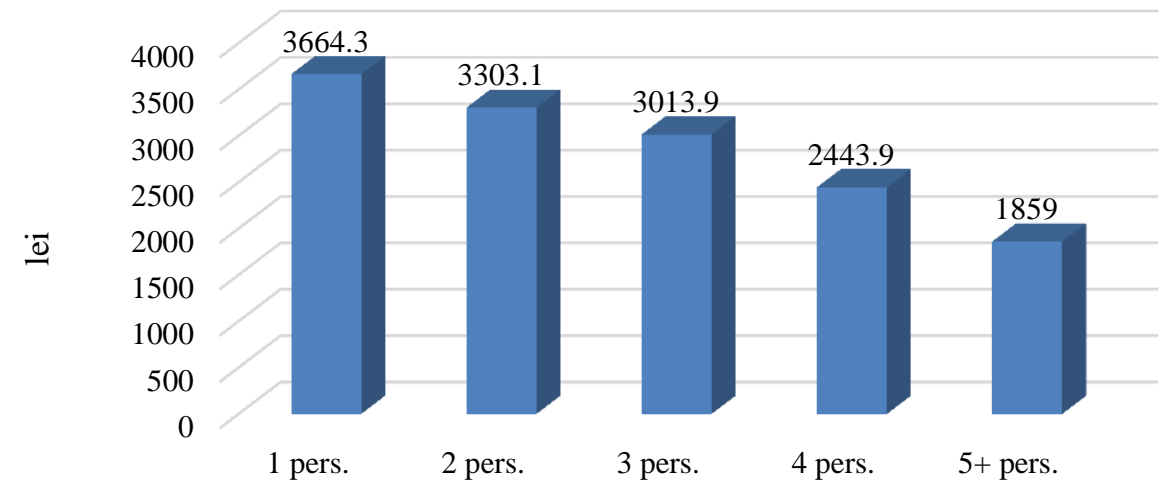

Figure 8. Disposable income by household size, Republic of Moldova, 2019

Source: Author representation 
The same tendency is registered depending on the number of children in the household; households with only one child registered income on average one person 1.5 times more than households with 3 or more children (Figure 9)

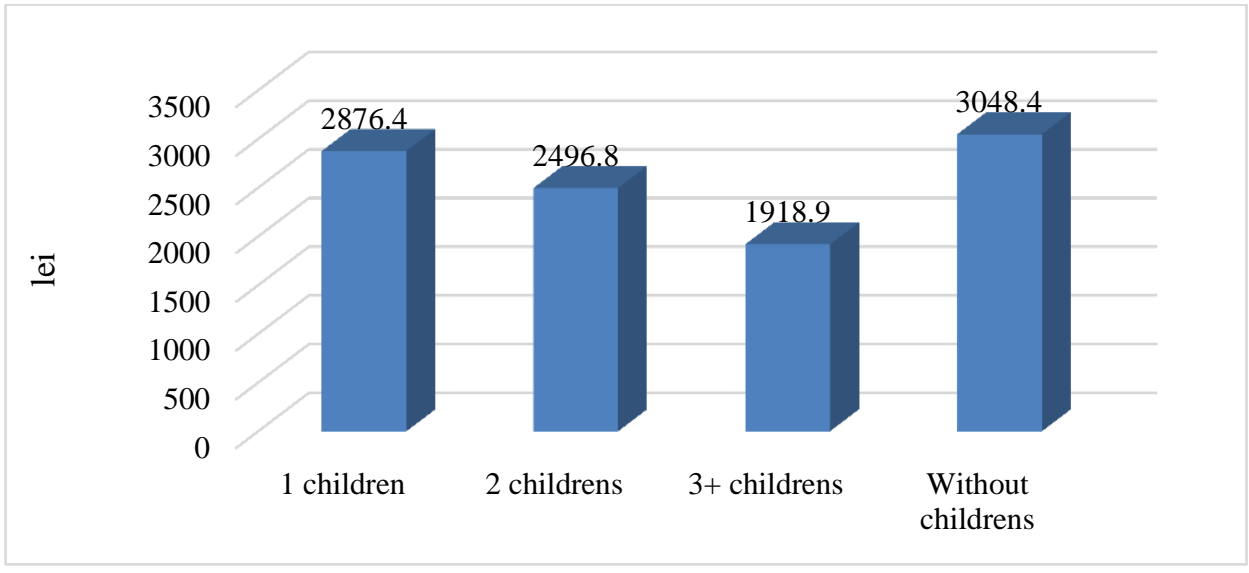

Figure 9. Disposable income by household composition, Republic of Moldova, 2019

Source: Author representation

It is clear that families with more children have lower incomes for one person as a result of the fact that in a family only adults bring financial resources into the family, and state aid is insignificant. In addition, the number of children in the family is dictated more by religion and traditional views of adults than by income level.

\subsection{Evolution of the consumption of population of the European Union and comparison with the consumption in Moldova}

According to Eurostat data (2014-2018), consumption in the European Union is largely oriented towards the payment of housing and communal services, while recreational expenditures are approximately at the same level as food procurement expenditures (Table 2), while in the Republic of Moldova food procurement expenditures represent a major point in the structure of expenditures (Figure 4).

During 2014-2018, the structure of expenditures in the European Union has changed. The share of consumption expenditures for recreation and leisure increased by 1.05 percentage point in 2018 compared to 2014 [2].

As it was mentioned, the largest share in the structure of expenditures belongs to the housing and communal services. Some of the factors that led to the modification of communal services in absolute value could be the modification of tariffs for electricity, gas, etc. 
Table 2. Level of consumption expenditures by groups in the European Union, euro per capita

\begin{tabular}{lccccc}
\hline $\begin{array}{l}\text { Consumer } \\
\text { spending group }\end{array}$ & 2014 & 2015 & 2016 & 2017 & 2018 \\
\hline $\begin{array}{l}\text { Food } \\
\begin{array}{l}\text { Clothing and } \\
\text { footwear }\end{array}\end{array}$ & 1710 & 1750 & 1760 & 1800 & 1840 \\
$\begin{array}{l}\text { Housing and } \\
\text { communal } \\
\text { services }\end{array}$ & 3790 & 3940 & 3910 & 3930 & 4020 \\
$\begin{array}{l}\text { Culture and } \\
\text { recreation }\end{array}$ & 1340 & 1430 & 1440 & 1490 & 1530 \\
\hline
\end{tabular}

The results of the dynamics analysis of electricity prices, gas prices for household consumers and expenditure for housing and communal services in the European Union showed that prices for energy resources did not have a significant impact on rising spending on communal services (Figure 10).

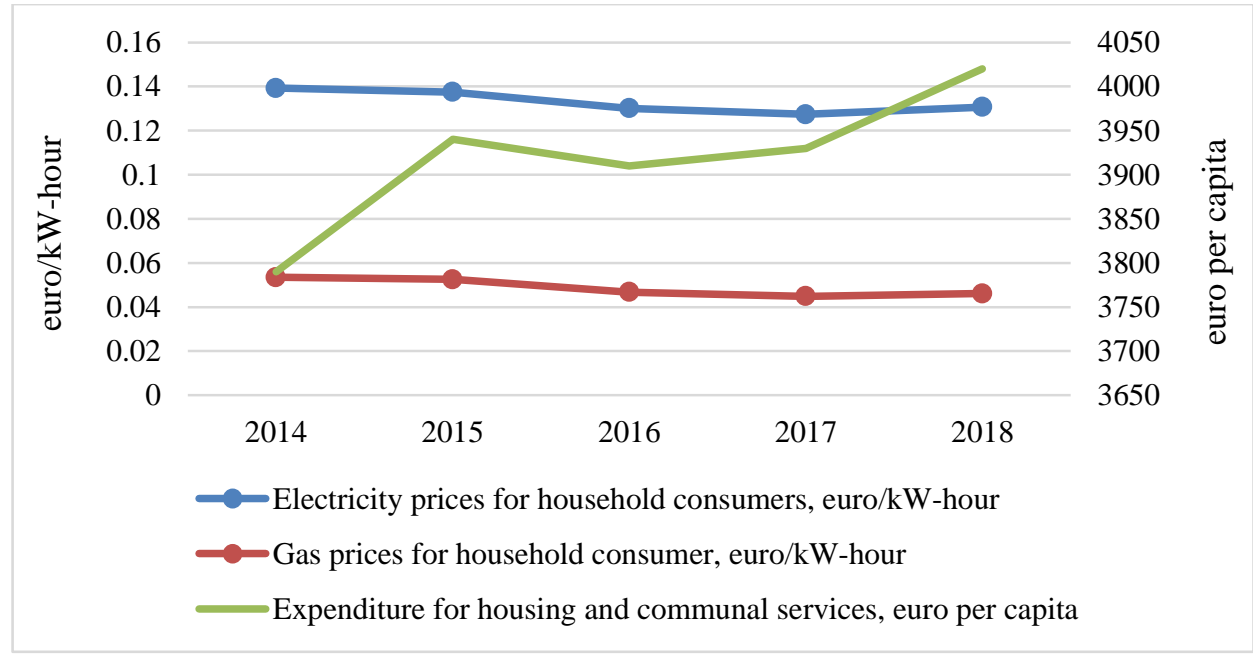

Figure 10. Evolution of electricity prices, gas prices for household consumers and expenditure for housing and communal services, the European Union, 2014-2018

Source: Author representation

Figure 11 shows the dynamics of EU consumer price index and the growth rate of some consumer spending groups. The EU consumer price index 
rose slowly, but growth rate of expenditure for home maintenance and clothes $\&$ shoes have grown considerably.

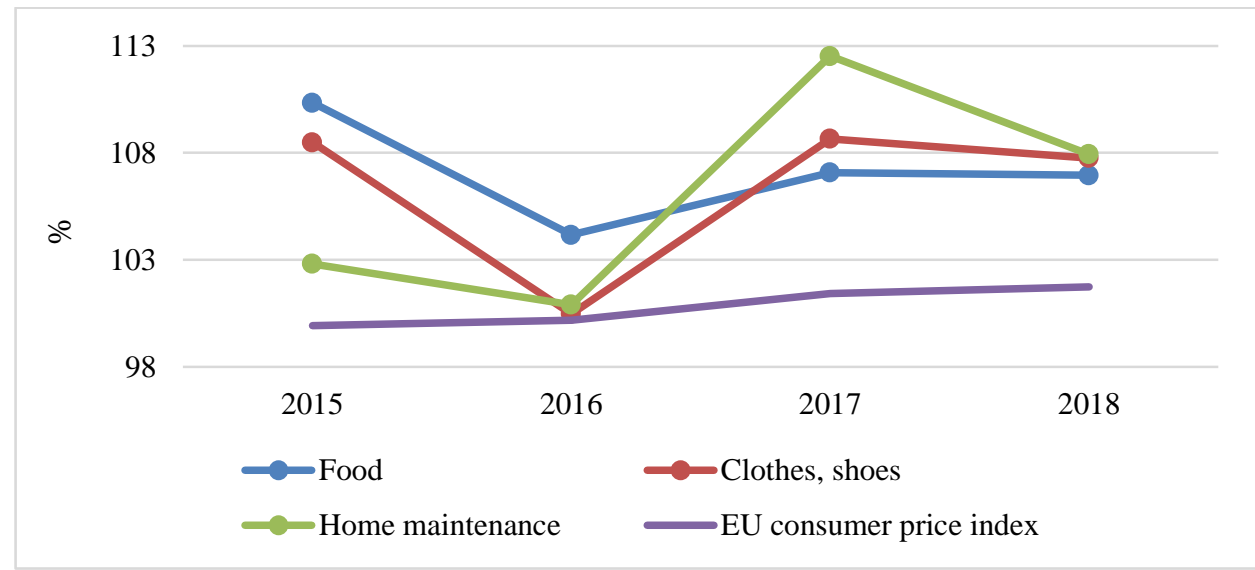

Figure 11. Dynamics of EU consumer price index and the growth rate of consumer spending groups, the European Union, 2015-2018

Source: Author representation

In the next paragraph it would be investigated how the consumer price index influences the dynamics of household expenditures in Moldova.

\subsection{The correlation between household expenditures and consumer price index in the Republic of Moldova}

The analysis of the dynamics of the price index and the consumption of the population of the Republic of Moldova by groups of goods and services showed that there is a correlation between these indicators (Figure 12).

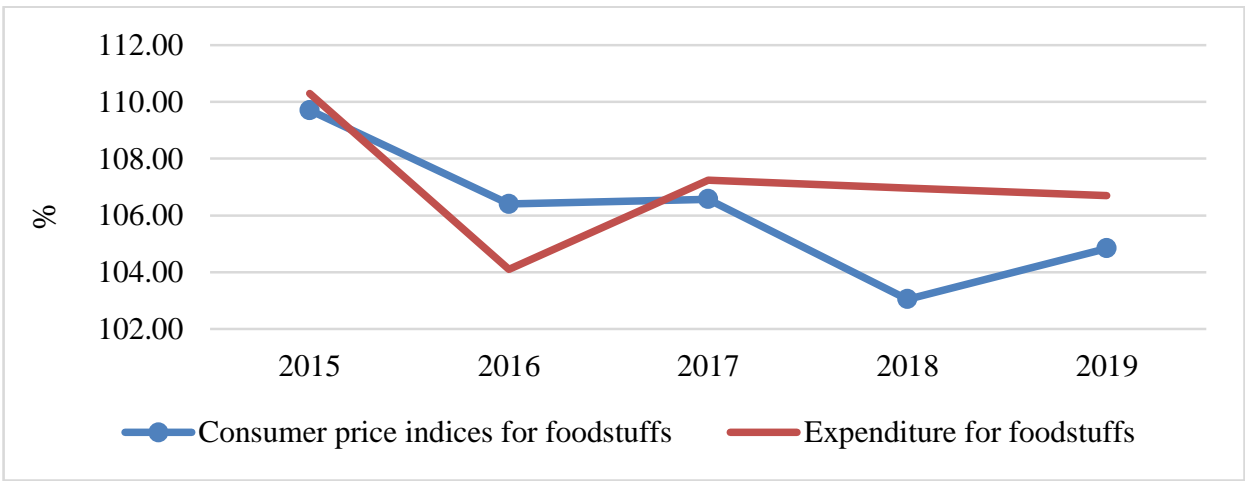

Figure 12. Dynamics of consumer price index and the growth rate of expenditure for food, Republic of Moldova

Source: Author representation 
In the case of non-food goods, the given correlation is more pronounced (Figure 13).

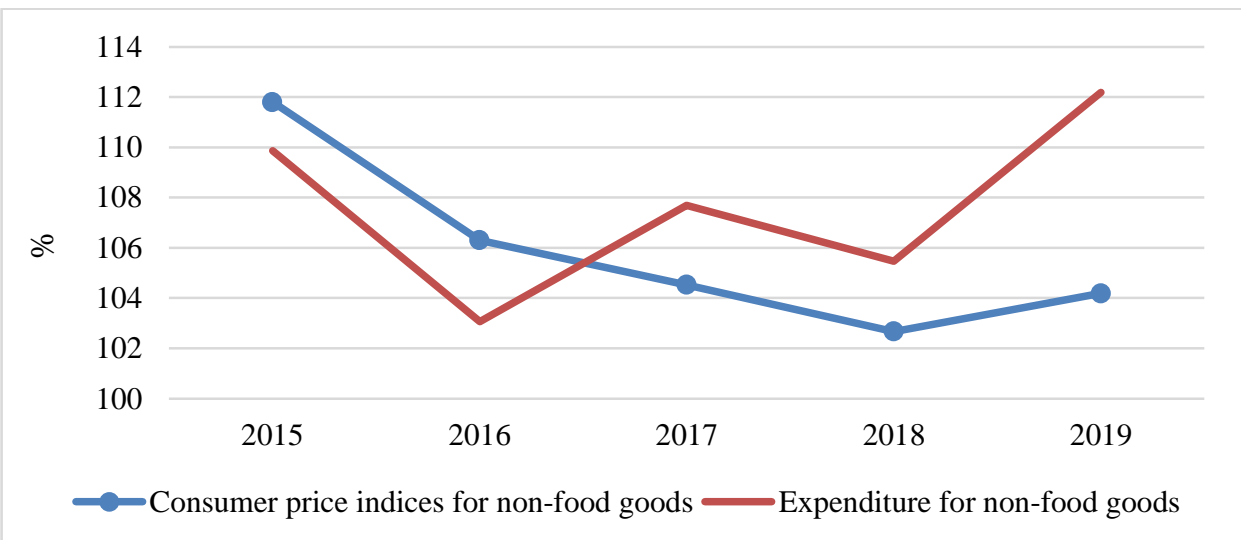

Figure 13. Dynamics of consumer price index and the growth rate of expenditure for non-food goods, Republic of Moldova

Source: Author representation

The method of correlation and regression analysis was used to prove or reject the assertion that the consumer price index has a significant impact on consumption. The null hypothesis $\mathrm{H} 0$ is that there is no linear regression between growth rate of household expenditures and consumer price index in the Republic of Moldova. Using the EViews9 software, the following linear regression equation was developed:

$y=4,737+0,969 \times C P I$

where: $\mathrm{y}$ - growth rate of household expenditures, $\%$;

IPC - consumer price index, \%.

This equation was statistically tested; the results are shown in the Table 3. If significance level is $5 \%$ and the p-value is equal 0,0027 , the null hypothesis for the regression parameter is rejected.

Table 3. Statistical testing of the linear regression model

\begin{tabular}{ll}
\hline Statistical tests & Value \\
\hline R-squared & 0.540711 \\
Adjusted R-squared & 0.502437 \\
F-statistic & 14,12736 \\
Probability (F-statistic) & 0.002728 \\
\hline
\end{tabular}

Source: Author results 
R-squared shows the fraction of the variance of the endogenous variable explained by the exogenous variable. The value of 0.540711 shows that the consumer price index is not the only factor influencing the level of the household consumption.

Therefore, one of the policies that the state must pursue in order to ensure the increase of the living standard of the population is the attenuation of inflation.

\section{Discussions}

The credibility of regression model which was elaborated depend from value of statistical tests. For continue this study it is need to research the influence of another factors. This would be purpose for the next study.

\section{Conclusions}

All objectives were realised and were identify the influence of the the consumer price index on consumption expenditures of population in case of the Republic of Moldova.

\section{References}

[1] Becker G. Comportamentul uman. O abordare economică. București: Editura, ALL; 1994.

[2] Eurostat [Internet]. Statistical databank [cited 2020 July 30]. Available from: https://ec.europa.eu/eurostat/data/database

[3] National Bureau of Statistics of the Republic of Moldova [nternet]. Statistical databank [cited 2020 July 30]. Available from: https://statistica.gov.md/pageview.php?1=en\&idc $=407 \&$ nod $=1 \&$

[4] Shahzad F, Waqas K, Imtiaz A. Effects of Inflation on Standard of Living (A case study of Multan, Pakistan). Universal Journal of Management and Social Sciences. 2012;2(12):1-6.

[5] Stiglitze J, Sen A, Fitoussi J. Report by the Commission on the Measurement of Economic Performance and Social Progress. France; 2009.

[6] Tassew D. The impact of inflation on living standard of households in Hawassa city, Ethiopia. 2015 [cited 2020 May 10]. Available from: https://www.researchgate.net/publication/323365856 THE_IMPACT_OF IINFLATION ON_LIVING STANDARD OF_HOUSEHOLDS_IN_H AWASSA CITY ETHIOPIA

[7] Varjan D. Economie si politici sociale. Bucuresti: EdituraASE; 2005. 